\title{
TANK MIXTURE OF PESTICIDES FOR Spodoptera frugiperda CONTROL IN MAIZE WITH TRIFLUMURON
}

\author{
MISTURA EM TANQUE DE PRODUTOS FITOSSANITÁRIOS NO CONTROLE DE \\ Spodoptera frugiperda NA CULTURA DO MILHO COM TRIFLUMURON
}

\section{César Henrique Souza ZANDONADI ${ }^{1}$; João Paulo Arantes Rodrigues da CUNHA ${ }^{2}$; Thales Cassemiro ALVES ${ }^{1}$; Sérgio Macedo SILVA ${ }^{3}$}

1. Doutorando do Programa de Pós-Graduação em Agronomia, Universidade Federal de Uberlândia - UFU, Uberlândia, MG, Brasil. cesarzandonadi@yahoo.com.br; 2. Professor, Doutor, Instituto de Ciências Agrárias- ICIAG - UFU, Uberlândia, MG, Brasil; 3. PósDoutorando, CAPES, UFU, Uberlândia, MG, Brasil

\begin{abstract}
Nowadays, few studies have been conducted to evaluate the effect of tank mixture of pesticides on pest chemical control in maize crops, however the farmers are often using these mixtures, without any technical support. The current study focused on assessing some pesticide mixtures to control Spodoptera frugiperda with triflumuron in a conventional corn hybrid. Moreover, this experiment aimed to assess likely plant physiological effects, as well as physical-chemical characteristics of these tank mixes. To this end, four treatments were carried out in a randomized block design with five replications, being repeated in two seasons. Treatments consisted of different pesticide mixtures, such as insecticide (INS) + adjuvant (ADJ); INS + ADJ + fungicide (FUN); INS + ADJ + FUN + foliar fertilizers (FF); control (Ctrl). The treatments underwent analyses of mixture physical-chemical characteristics, sampled caterpillar number and size, leaf gas exchange (IRGA), and amount of chlorophyll a and b. Spray liquid characteristics changed with used mixture. Fertilizer addition caused major changes in spray liquid properties as increasing $\mathrm{pH}$ and electrical conductivity. No effect was observed by mixing azoxystrobin, cyproconazole, zinc oxide and manganese sulfate to triflumuron concerning control effectiveness of Spodoptera frugiperda in the corn plants. Conversely, each pesticide mixture had a distinct effect on plant physiological variables.
\end{abstract}

KEYWORDS: Application technology. Gas exchange. Physico-chemical characteristics. Zea mays.

\section{INTRODUCTION}

Plant protection products (pesticides) are extremely important to reach maximum field yields. Mixing products of distinctive functions is commonly used, being important mainly to reduce the number of sprayings and environmental contamination and, consequently, decreasing final production cost (CASTRO, 2009). A main example of such mixtures is the combination of foliar fertilizers and adjuvants with xenobiotics like fungicides, insecticides and herbicides. Nowadays, about $97 \%$ of farmers have been using tank mixes and, in most cases (95\%), blending up to five different products within the tank (GAZZIERO, 2015), especially for great expression crops as soybean and maize.

On the other side, chemical mixtures may generate variations on spray liquid physicalchemical properties, which might affect directly or indirectly their absorption on leaf surface, thus affecting their effectiveness (CUNHA; ALVES 2009).

Maize (Zea mays L.) is one of the most grown cereals worldwide and the second most produced in Brazil (CONAB, 2016). This crop has great economic and social importance, either by its grain use in human and animal feeding or as a raw material for industry. Pesticide spraying in maize crops are held in both vegetative and reproductive stages. During vegetative phase, mixes of insecticides, fungicides, adjuvants and foliar fertilizers are applied to corn plants.

Notwithstanding, pesticide performance may vary under adverse environmental and application conditions; therefore, adjuvants could improve spray efficiency, since they might influence mixture physical-chemical characteristics (CUNHA, ALVES and REIS, 2010; KISSMAN, 1998). Nevertheless, by lack of knowledge on mode of action and potential negative interactions between adjuvants and pesticide, farmers may compromise spraying effectiveness (PUTTI et al., 2014).

Even though responses about the effects of these pesticide mixtures in maize farming are quite important; currently, few studies are engaged in investigating them. For these reason, the objectives of this study were to test different pesticide mixtures to control Spodoptera frugiperda in conventional corn hybrid, to ascertain further plant physiological impacts, and to analyze spray mixture physicalchemical properties. 


\section{MATERIAL AND METHODS}

\section{Experimental Site}

Field experiments were conducted at Capim Branco farm, experimental area of the Federal University of Uberlândia. It is located at $18^{\circ} 53^{\prime}$
ZANDONADI, C. H. S. et al.

23.46" S latitude, $48^{\circ} 20^{\prime} 27.46^{\prime \prime} \mathrm{W}$ longitude, and $842 \mathrm{~m}$ altitude. The experiment was carried out in two different periods: the first in January 2016 (Experiment 1) and the second in March 2016 (Experiment 2). Figure 1 displays the records of rainfall and mean temperature during field experiment.

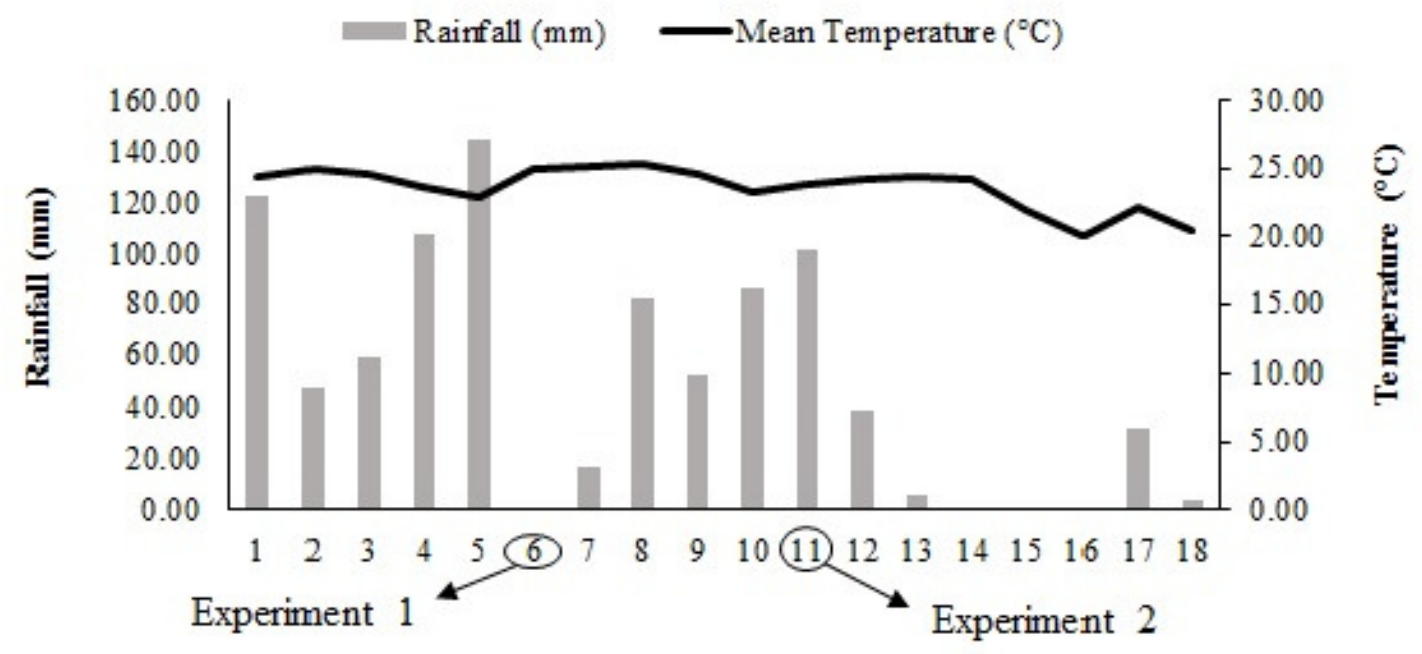

Period of ten days (01/12/2015 a 28/05/2016)

Figure 1. Mean temperature $\left({ }^{\circ} \mathrm{C}\right)$ and accumulated rainfall $(\mathrm{mm})$ throughout ten-day period (December 2015 to May 2016) in Uberlândia - MG, Brazil.

\section{Treatments}

Both experiments were conducted to evaluate the effectiveness of different pesticide mixtures within spray tanks in controlling $S$. Frugiperda. Table 1 describes the used products in all treatments and their respective specifications.

Table 1. Specifications of the used products.

\begin{tabular}{|c|c|c|c|c|}
\hline Product & Function & $\begin{array}{c}\text { Concentratio } \\
n\end{array}$ & $\begin{array}{c}\text { Formulation } \\
*\end{array}$ & Dose \\
\hline Triflumuron $\left(\right.$ Certero $\left.^{\circledR}\right)$ & Insecticide & $480 \mathrm{~g} \mathrm{~L}^{-1}$ & SC & $100 \mathrm{~mL} \mathrm{ha}^{-1}$ \\
\hline Paraffinic mineral oil & Adjuvant & $428 \mathrm{~g} \mathrm{~L}^{-1}$ & $\mathrm{EC}$ & $500 \mathrm{~mL} \mathrm{ha}^{-1}$ \\
\hline $\begin{array}{l}\text { Azoxystrobin + cyproconazole (Priori } \\
\text { Xtra }^{\circledR} \text { ) }\end{array}$ & Fungicide & $280 \mathrm{~g} \mathrm{~L}^{-1}$ & $\mathrm{SC}$ & $400 \mathrm{~mL} \mathrm{ha}^{-1}$ \\
\hline Zinc oxide & Foliar fertilizer & $100 \%$ & & $200 \mathrm{~mL} \mathrm{ha}^{-1}$ \\
\hline Manganese sulfate & Foliar fertilizer & $30 \%$ & & $300 \mathrm{~mL} \mathrm{ha}^{-1}$ \\
\hline
\end{tabular}

*SC - Suspension concentrate; EC - Emulsifiable concentrate.

Physical-chemical properties of the mixtures were analyzed in the Laboratory of Agricultural Mechanization (LAMEC) of the Federal University of Uberlândia (UFU), besides testing the likely field effectiveness of sprays. Treatments were composed of three different combinations between the products, at the recommended doses, and one control without spraying. Preparation of the treatments followed the following order, with an interval of one minute for stirring: Treatment 1 Triflumuron + Mineral Oil; Treatment 2 Triflumuron + Azoxystrobin + Cyproconazole + Mineral Oil; Treatment 3 - Triflumuron + Azoxystrobin + Cyproconazole + Mineral Oil + Zinc oxide + Manganese sulfate; and Treatment 4 Control. 


\section{Experiment Conduction}

Silage maize, hybrid Nidera NS82®, was sown row spacing of $0.50 \mathrm{~m}$, with a population of 60,000 plants per hectare. Sowing fertilization was carried out with $300 \mathrm{~kg} \mathrm{ha}^{-1}$ of 08: 28: $16\left(\mathrm{~N}: \mathrm{P}_{2} \mathrm{O}_{5}\right.$ : $\mathrm{K}_{2} \mathrm{O}$ ), according to the crop demand. In both experiments, topdressing was performed applying $300 \mathrm{~kg} \mathrm{ha}^{-1}$ of 20: 00: $20\left(\mathrm{~N}: \mathrm{P}_{2} \mathrm{O}_{5}: \mathrm{K}_{2} \mathrm{O}\right)$ at the fourleaf stage (V4).

First experiment plots had an area of $20 \mathrm{~m}^{2}$ and eight 5-m planting rows. Yet in the second, each plot covered an area of $32 \mathrm{~m}^{2}$ with eight 8-m rows.

Sprayings were carried out with a $\mathrm{CO}_{2}$ pressurized backpack sprayer at $300 \mathrm{kPa}$ constant pressure and $150 \mathrm{~L} \mathrm{ha}^{-1}$ spray volume, with four flatfan nozzles (110.02BD) spaced by $0.5 \mathrm{~m}$. The spray was realized at a working speed of $6 \mathrm{~km} \mathrm{~h}^{-1}$. Environmental conditions during applications were monitored by a portable weather meter (model Kestrel 4000, Kestrel).

In experiment 1, first application was on February 19 (between 09h45 and 10h00 am), which was 23 days after crop emergence - DAE (V5/6 crop stage) (FEHR; CAVINES, 1977). During spraying, temperature (T) ranged from 23.8 to 25.9 ${ }^{\circ} \mathrm{C}$, relative humidity (RH) between 76.1 and $85.1 \%$, and wind speed (WS) from 3.3 to $5.4 \mathrm{~km} \mathrm{~h}^{-1}$. Whereas the second application was performed on February 29 between $10 \mathrm{~h} 48$ and $10 \mathrm{~h} 59$ am (33 DAE). This time, T variation was of 29.8 and 30.8 ${ }^{\circ} \mathrm{C}$, RH from 48.6 to $55.4 \%$, and WS between 3.4 and $5.0 \mathrm{~km} \mathrm{~h}^{-1}$.

In experiment 2, the first treatment was sprayed on April 07 between 09h18 and 09h39 am (20 DAE). During application, T varied from 28.4 to $30.1{ }^{\circ} \mathrm{C}$, RH between 49.8 and 54.5, and WS from 3.2 to $4.8 \mathrm{~km} \mathrm{~h}^{-1}$. Yet the second application was held on April 13 between 17h08 and 17h30 am (26 DAE). Alongside T varied between 28.7 and 29.7 ${ }^{\circ} \mathrm{C}, \mathrm{RH}$ from 49.4 to $56.6 \%$, and WS of 3.8 to 5.5 $\mathrm{km} \mathrm{h}^{-1}$.

\section{Evaluations}

\section{Physical-chemical evaluations}

Different tank mixtures were prepared with pesticides in the laboratory, before the field experiments, to evaluate the spray solution physicalchemical properties as density, $\mathrm{pH}$, electrical conductivity, viscosity and surface tension. In the ways of comparison, it was evaluated distilled water.

Density was calculated as weight of spray solution $(0.1 \mathrm{~L})$ divided by its volume in a volumetric flask, with a precision scale of $0.1 \mathrm{mg}$ (CUNHA, ALVES and REIS, 2010). Electrical conductivity and $\mathrm{pH}$ were directly measured in the solution, using a combined $\mathrm{pH}$ and conductivity meter (Hach, HQ40d).

Dynamic viscosity was determined using a viscometer (Quimis, Q860M21) obtaining electronic measures of shearing force in viscosity. This device operates by rotation of a cylinder immersed in the sample to be tested, thus measuring the torsional force required to brake rotational force. The equipment was operated at $60 \mathrm{rpm}$ and rotor at zero, which is prescribed for the measured viscosity range.

Surface tension was determined using a bench tensiometer with platinum ring (Kruss, K6) and the Du Nouy method (DOPIERALA; PROCHASKA, 2008), calibrating the equipment with distilled water.

\section{Biological effectiveness of the treatments}

Biological effectiveness evaluations were made within the four central rows, discarding $0.5 \mathrm{~m}$ of each line end. Prior to spraying at V3 stage, $S$. frugiperda was monitored in five plants per plot, removing their corn whorl (whole leaves no-fully developed) for armyworm counting and weighting. Such monitoring was performed again at three, ten, and fourteen days after first treatment application (DAA), as method described before.

Additionally, 20 plants within floor area of each plot were randomly selected for a visual analysis of damages, scoring each individual from 0 to 9, following method proposed by Davis et al. (1992) and adapted by Fernandes et al. (2003).

\section{Physiological evaluations (gas exchange, foliar chlorophyll index and chlorophyll a fluorescence)}

Physiological evaluations were performed during the morning, one day before and one after the first treatment application. Mean temperature and air humidity during evaluations were of about $26^{\circ} \mathrm{C}$ and $70 \%$, respectively.

$\mathrm{CO}_{2}$ assimilation (A, $\mu \mathrm{mol} \mathrm{m} \mathrm{m}^{-2} \mathrm{~s}^{-1} \mathrm{CO}_{2}$ ), foliar transpiration $\left(\mathrm{E}, \mathrm{mmol} \mathrm{m} \mathrm{m}^{-2} \mathrm{~s}^{-1} \mathrm{H}_{2} \mathrm{O}\right)$, stomata conductance $\left(\mathrm{gs}, \mathrm{mol} \mathrm{m}^{-2} \mathrm{~s}^{-1} \mathrm{H}_{2} \mathrm{O}\right)$ and intercellular carbon (ci, $\mu \mathrm{mol} \mathrm{m} \mathrm{m}^{-2} \mathrm{~s}^{-1} \mathrm{CO}_{2}$ ) were evaluated with a gas exchange meter (IRGA - Infrared Gas Analyzer - model LCpro-SD, ADC BioScientific Ltda). Artificial light inside chamber was provided during measurements, making sure plants received a photon flux density of $1200 \mu \mathrm{mol} \mathrm{m} \mathrm{m}^{-2} \mathrm{~s}^{-1}$. Three 
readings were made on fully developed leaves of two plants per replication.

From these IRGA measurements, it was calculated instantaneous water use efficiency (A/E), intrinsic water use efficiency $(\mathrm{A} / \mathrm{gs})$ and carboxylation efficiency (A/ci).

The relative chlorophyll $\mathrm{a}$ and $\mathrm{b}$ contents were measured by a chlorophyll meter (ClorofiLOG CFL-1030, Falker Automação Agrícola) and expressed as Falker chlorophyll index (FCI). The readings were taken on the foliar limbo of completely developed leaves. For chlorophyll, two transmitters were employed to capture two different wavelengths, near the peak of each chlorophyll type response $(\lambda=635$ and $660 \mathrm{~nm})$, and an emitter with wavelengths in the near infrared $(\lambda=880 \mathrm{~nm})$.

The same plants used in chlorophyll index survey were used to measure chlorophyll a fluorescence, which was carried out within the same period of gas exchange and chlorophyll index ones.

Minimum and maximal fluorescence yields (F0 and Fm), in the photosystem II (PSII) and adapted dark conditions, were evaluated by fluorescence analysis of chlorophyll a (Mini-PAM, Walz). The dark condition was set after 30-min simulated dark using metal dark-adaptation clips (DLC-8). Under this condition, PSII fluorescence was monitored being induced by a pulse of light (saturation pulse of $0.8 \mathrm{~s}$ ), enabling calculation of PSII maximum quantum yield, like the Equation 1. $\phi P S I I=\frac{F m-F 0}{F m}$

All the physiological evaluations were carried out one day before pesticide spraying (for both experiments) as parameter for further evaluations, after application, showing likely influence of treatments on these factors.

\section{Experimental design and statistics}

A randomized block design was adopted, with four treatments and five replications. Data means were tested for normal error distribution using a Shapiro-Wilk normality test, for variance homogeneity by Levene's test, and for block additivity by the F-test of Tukey, at a 0.01 significance level, using SPSS Statistical Software, version 17.0 (SPSS Inc., Chicago, IL, USA).

Then, variance analysis was applied and, when significant, means were compared by the Scott-Knott's test at 0.05 probability level.

\section{RESULTS AND DISCUSSION}

\section{Physical-chemical evaluations}

Table 2 shows all physical-chemical properties being influenced by the different mixtures.

Table 2. Physical-chemical properties of water and pesticide mixtures sprayed on maize crop.

\begin{tabular}{|c|c|c|c|c|c|}
\hline Spray & $\begin{array}{l}\text { Hydrogen } \\
\text { potential } \\
(\mathrm{pH})\end{array}$ & $\begin{array}{l}\text { Electrical } \\
\text { conductivity } \\
\left(\mu \mathrm{S} \mathrm{cm}^{-1}\right)\end{array}$ & $\begin{array}{l}\text { Density } \\
\left(\mathrm{g} \mathrm{cm}^{-3}\right)\end{array}$ & $\begin{array}{l}\text { Viscosity } \\
\left(\mathrm{mPa} \mathrm{s}^{-1}\right)\end{array}$ & $\begin{array}{l}\text { Surface } \\
\text { tension } \\
\left(\mathrm{mN} \mathrm{m}^{-1}\right)\end{array}$ \\
\hline Water & $6.02 \mathrm{~B}$ & $1.40 \mathrm{D}$ & $1.00 \mathrm{~A}$ & $1.32 \mathrm{~A}$ & $72.50 \mathrm{C}$ \\
\hline Triflumuron + mineral oil & $4.67 \mathrm{D}$ & $63.85 \mathrm{C}$ & $0.98 \mathrm{~B}$ & $1.11 \mathrm{~B}$ & $31.00 \mathrm{~B}$ \\
\hline $\begin{array}{l}\text { Triflumuron + mineral oil + } \\
\text { azoxystrobin/cyproconazole }\end{array}$ & $5.29 \mathrm{C}$ & $87.45 \mathrm{~B}$ & $0.98 \mathrm{~B}$ & $1.10 \mathrm{~B}$ & $26.75 \mathrm{~A}$ \\
\hline $\begin{array}{l}\text { Triflumuron }+ \text { mineral oil }+ \\
\text { azoxystrobin/cyproconazole }+\mathrm{Zn}+ \\
\text { Mn }\end{array}$ & $6.85 \mathrm{~A}$ & $723.50 \mathrm{~A}$ & $0.99 \mathrm{~B}$ & $1.14 \mathrm{~B}$ & $27.00 \mathrm{~A}$ \\
\hline CV (\%) & 3.78 & 4.24 & 0.50 & 8.97 & 2.17 \\
\hline F & $76.001 *$ & $5302.169 *$ & 7.047* & $4.050 *$ & $2706.103 *$ \\
\hline$F_{\text {levene }}$ & $3.689 *$ & $1.614^{*}$ & $1.649 *$ & $3.767 *$ & $3.279^{*}$ \\
\hline SW & $0.847 *$ & $0.909^{*}$ & $0.850^{*}$ & $0.703 *$ & $0.854^{*}$ \\
\hline
\end{tabular}

Different uppercase letters in the same column indicate differences according to the Scott-Knott's test at 5\% significance level. F - F value of each treatment. $\mathrm{F}_{\text {levene }}$ - Levene test, $\mathrm{SW}$ - Shapiro-Wilk test. * significant at 5\%.

Mixtures decreased solution density and viscosity whether compared to distilled water (control). The smallest values of density might have been influenced by mineral oil addition.

Surface tension deeply decreased with the use of these different products. It was noteworthy that combining insecticide, adjuvant, and fungicide, with or without foliar fertilizer, provided the lowest levels for this variable. Even though the used mineral oil showed a hypotensive effect, as stated by Baio et al. (2015), not all mineral oils present this feature, since their action on solution physical- 
chemical properties are dependent on their chemical composition (IOST; RAETANO, 2010; SILVA et al., 2006).

Control electrical conductivity values were lower than the mixtures were. An increasing trend was observed as a different pesticide was added to the mix. Given that, treatments receiving foliar fertilizers reached the highest electrical conductivity values. This variable is related to the amount of ions in the solution and respective concentration and charges, therefore, depends on product composition.

The $\mathrm{pH}$ varied differently from the other properties, reaching a value of 6.02 for water. By adding insecticide and adjuvant, this value dropped to 4.67. Likewise, Maciel et al. (2010) reported that the same mineral oil as the one used here had lowered the $\mathrm{pH}$ of spraying solution. In contrast, when adding the fungicide into the mixture, the $\mathrm{pH}$ increased, as well as for foliar fertilizer, which further increased such levels, differing from other treatments.
Similarly as found by Cunha and Alves (2009), pH, surface tension, and viscosity were most sensitive to adjuvant addition in comparison with pure water. Interestingly, Andrade et al. (2013) reported that foliar fertilizer adding to pesticide mixtures have influence on spray physical-chemical characteristics, mainly on $\mathrm{pH}$ and electrical conductivity. These data corroborate with those presented in this paper.

\section{Biological effectiveness of treatments}

The Davis scale was not used in the first experiment because all plots had an infestation index was above the threshold for control, impairing the use of such scale. Through Table 3 , it is notable a reduction on caterpillar number at 14 DAA, when contrasting all treatments and the control; however, it was not noticed difference from addition of fungicides and fertilizers. Caterpillar size behaved the same way, whereas armyworm sizes were larger when pesticides were not applied.

Table 3. Biological effectiveness of the different pesticide mixtures in maize against Spodoptera frugiperda.

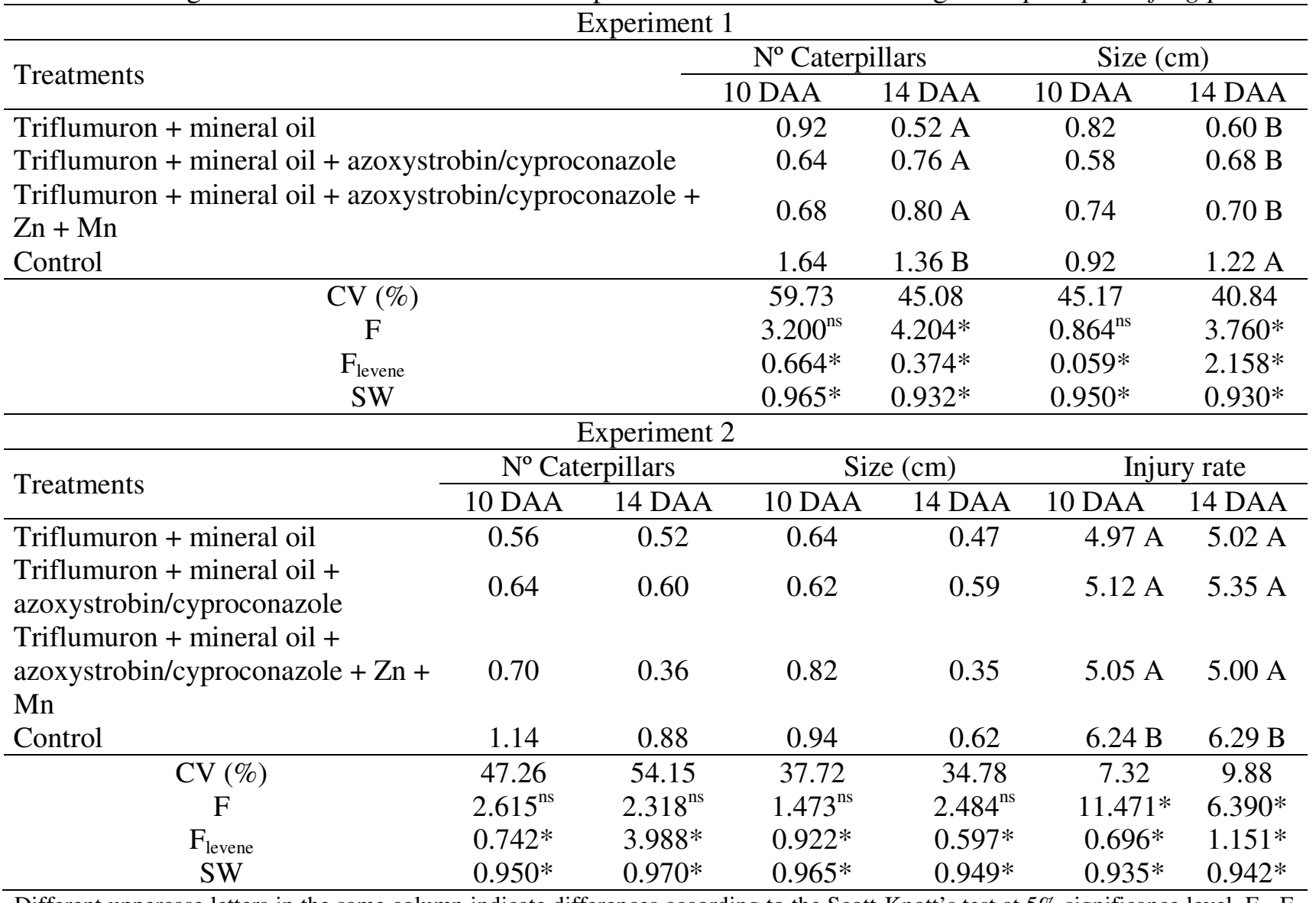

Different uppercase letters in the same column indicate differences according to the Scott-Knott's test at 5\% significance level. F - F value of each treatment. $\mathrm{F}_{\text {levene }}$ - Levene test. SW - Shapiro-Wilk test. * significant at $5 \%$. 
Regarding foliar fertilizer in combination with insecticides, Andrade et al. (2013) found no losses of effectiveness for mixtures with insecticide and zinc fertilizer, corroborating the current results.

When evaluating mixtures of insecticides (including triflumuron) and sulphur-based foliar fertilizer, Guerrero et al. (2013) reported no difference regarding the number of caterpillar, neither mixtures nor individual application, thus being similar to the results of this study. According to the same authors, triflumuron low efficiency could be related to a small number of newborn armyworms, which is the main biological target of this product.

Likewise, it was found only differences from treated to untreated plants in the second experiment. Moreover, the addiction of fungicide and foliar fertilizer to the spray tank showed no effect on plants according to visual assessment.

Figure 1 emphasizes a quite long period of water stress during the second experiment, which might have affected plant growth. Therefore, such event may have influenced spraying efficacy. Despite the different control results in accordance with visual scale of Davis, there was no difference concerning the number and size of armyworms among treatments, probably due to this water stress period.

\section{Physiological evaluations}

Table 4 displays the physiological evaluations carried out in experiments 1 and 2 .

Regarding experiment 1 , net photosynthesis estimates in all treatments were different from control (March 1) in pre-application. Pesticide mixtures affected plant transpiration and instantaneous water use efficiency, showing reduced values in contrast to control. Overall, had an increase of these variables on days $22 / 02$ to $01 / 03$, fact that showed the effect of the products.

In the literature, a few reports are found regarding individual effect of pesticides on plant physiological aspects, such as for foliar fertilizers (HUSSAIN et al., 2016; FEIJAO et al. 2011; SOUSA et al. 2010), fungicides (TORRES et al. 2012) and insecticides (LEMES et al. 2015). Nonetheless, so far nothing has been related concerning the effect of mixture of all these products in the scientific literature.

In relation to chlorophyll content (experiment 1), these were higher on the treatments that had the mixture of all products, as well as in the control.
The maximum quantum yield of photosystem II and chlorophyll $b$ had no influence from any of the treatments in both experiments. The first variable can be used for diagnosis photosynthetic apparatus integrity (PEREIRA et al. 2000), which is largely used to evaluate biotic and abiotic stress responses, mainly related to hydric stress (TORRES et al., 2012; SUASSUNA et al., 2010). According to Björkman (1987), the values achieved here (between 0.76 and 0.81 ) are within normal amplitude seen a correct function of PSII in plants $(0.75$ to 0.85$)$, showing no photo-inhibition throughout evaluation period.

Instantaneous water use efficiency increased somewhat comparing control to preapplication. In general, mixture applications showed significant reduction on these values, presenting a trend of decreasing water use efficiency by plants.

Mixtures influenced the carboxylation efficiency of rubisco except for the one with all products, which had values similar to control. Mixtures without foliar fertilizers had negative influence regarding plant $\mathrm{CO}_{2}$ sequestration in leaf tissues.

Lemes et al. (2015), evaluating different chemical groups of insecticides on corn physiological parameters, found a positive impact for triflumuron on rubisco carboxylation efficiency, besides noticing improvements of about $60 \%$ compared to treatments without application of any pesticide.

In experiment 2, treatments with foliar fertilizer showed negative impact on both intrinsic water use efficiency and carboxylation efficiency of rubisco. Indeed, intrinsic water use efficiency stands for stomatal transpiration rate, hence being directly affected by stomata opening. This treatment also presented higher values of electrical conductivity (Table 2) that indicates a broader amount of ions in solution compared to the other treatments, influencing the results of this variable.

Solutions with higher electrical conductivity have negative impact on stomatal conductance and net photosynthesis (SILVA et. al., 2013). These authors also claimed that a possible reason for that comes from partial closing of the stomata, which in turn, is due to large-scale presence of ions in solution. Burkhardt et al. (2009), analyzing interactions between salt-based products used in foliar fertilizations, reported negative effect of these salts both on photosynthesis rate and on water use efficiency of apple trees. 
Table 4. Evaluations of foliar gas exchanges and their relations, efficiency of photosystem II and chlorophylls in a conventional maize hybrid NS82 treated with different pesticides in mixture.

\begin{tabular}{|c|c|c|c|c|c|c|c|c|}
\hline \multicolumn{9}{|c|}{ Experiment 1} \\
\hline Treatments & $\mathrm{A}^{a}$ & $\mathrm{E}^{b}$ & $A / E^{\mathrm{c}}$ & $A / g s^{\mathrm{d}}$ & $A / c i^{\mathrm{e}}$ & $\varnothing \mathrm{PSII}^{\mathrm{f}}$ & $\mathrm{Chl} \mathrm{a}^{\mathrm{g}}$ & Chl b $^{\mathrm{g}}$ \\
\hline Triflumuron + mineral oil $(01 / 03)$ & $38.52 \mathrm{~A}$ & $4.16 \mathrm{~B}$ & $9.61 \mathrm{~B}$ & 105.84 & $0.41 \mathrm{~B}$ & 0.80 & $34.74 \mathrm{~B}$ & 13.42 \\
\hline $\begin{array}{l}\text { Triflumuron + mineral oil + } \\
\text { azoxystrobin/cyproconazole }(01 / 03)\end{array}$ & $37.70 \mathrm{~A}$ & $4.23 \mathrm{~B}$ & $9.17 \mathrm{~B}$ & 100.54 & $0.37 \mathrm{~B}$ & 0.81 & $34.94 \mathrm{~B}$ & 14.06 \\
\hline $\begin{array}{l}\text { Triflumuron }+ \text { mineral oil + azoxystrobin/ } \\
\text { cyproconazole }+\mathrm{Zn}+\mathrm{Mn}(01 / 03)\end{array}$ & $40.86 \mathrm{~A}$ & $4.40 \mathrm{~B}$ & $9.35 \mathrm{~B}$ & 101.76 & $0.47 \mathrm{~A}$ & 0.81 & $36.78 \mathrm{~A}$ & 14.56 \\
\hline Control $(01 / 03)$ & $41.36 \mathrm{~A}$ & $5.11 \mathrm{~A}$ & $11.79 \mathrm{~A}$ & 124.72 & $0.46 \mathrm{~A}$ & 0.80 & $36.22 \mathrm{~A}$ & 15.18 \\
\hline Pre-application (22/02) & $33.99 \mathrm{~B}$ & $2.88 \mathrm{C}$ & $8.08 \mathrm{~B}$ & 103.32 & $0.49 \mathrm{~A}$ & 0.79 & $35.32 \mathrm{~B}$ & 15.52 \\
\hline $\mathrm{CV}$ & 7.79 & 12.70 & 10.59 & 12.18 & 15.19 & 1.39 & 2.87 & 7.58 \\
\hline $\mathrm{F}$ & $4.831 *$ & $11.643^{*}$ & $7.046^{*}$ & $2.364^{\mathrm{ns}}$ & $2.435^{*}$ & $1.509^{\mathrm{ns}}$ & $3.439 *$ & $4.138^{\mathrm{ns}}$ \\
\hline $\mathrm{F}_{\text {levene }}$ & $0.664 *$ & $1.327 *$ & $0.724 *$ & $0.826 *$ & $2.242 *$ & $0.666 *$ & $1.947 *$ & $0.527 *$ \\
\hline SW & $0.980 *$ & $0.970 *$ & $0.988 *$ & $0.941 *$ & $0.957 *$ & $0.980 *$ & $0.972 *$ & $0.973 *$ \\
\hline \multicolumn{9}{|c|}{ Experiment 2} \\
\hline Triflumuron + mineral oil (14/04) & $22.26 \mathrm{~B}$ & 2.35 & 9.60 & $163.71 \mathrm{~A}$ & $0.39 \mathrm{~A}$ & 0.77 & 31.48 & 10.22 \\
\hline $\begin{array}{l}\text { Triflumuron }+ \text { mineral oil }+ \\
\text { azoxystrobin/cyproconazole }(14 / 04)\end{array}$ & $26.92 \mathrm{~A}$ & 2.73 & 9.92 & $143.20 \mathrm{~A}$ & $0.38 \mathrm{~A}$ & 0.76 & 31.04 & 10.08 \\
\hline $\begin{array}{l}\text { Triflumuron + mineral oil + azoxystrobin/ } \\
\text { cyproconazole }+\mathrm{Zn}+\mathrm{Mn}(14 / 04)\end{array}$ & $22.54 \mathrm{~B}$ & 2.68 & 8.46 & $117.75 \mathrm{~B}$ & $0.20 \mathrm{~B}$ & 0.77 & 30.02 & 9.78 \\
\hline Control $(14 / 04)$ & $22.37 \mathrm{~B}$ & 2.27 & 9.89 & $160.66 \mathrm{~A}$ & $0.42 \mathrm{~A}$ & 0.77 & 30.36 & 9.58 \\
\hline Pre-application $(08 / 04)$ & $31.50 \mathrm{~A}$ & 2.93 & 10.74 & $126.60 \mathrm{~B}$ & $0.43 \mathrm{~A}$ & 0.77 & 32.98 & 12.32 \\
\hline $\mathrm{CV}$ & 21.32 & 22.01 & 11.20 & 12.89 & 30.70 & 2.44 & 8.36 & 14.60 \\
\hline $\mathrm{F}$ & $2.892 *$ & $1.158^{\mathrm{ns}}$ & $2.278^{\mathrm{ns}}$ & $5.336 *$ & $2.607 *$ & $0.236^{\mathrm{ns}}$ & $0.812^{\mathrm{ns}}$ & $2.117^{\mathrm{ns}}$ \\
\hline$F_{\text {levene }}$ & $0.228 *$ & $1.796 *$ & 0.599 & 0.263 & $1.698 *$ & $1.967 *$ & $1.269 *$ & $0.546^{*}$ \\
\hline SW & $0.980 *$ & $0.973 *$ & $0.936^{*}$ & $0.978 *$ & $0.932 *$ & $0.978 *$ & $0.943 *$ & $0.931 *$ \\
\hline
\end{tabular}

$a$ : net photosynthesis $\left(\mu \mathrm{mol} \mathrm{m}^{-2} \mathrm{~s}^{-1}\right) ; b$ : transpiration $\left(\mathrm{E}, \mathrm{mmol} \mathrm{m}^{-2} \mathrm{~s}^{-1}\right) c$ : instantaneous water use efficiency $\left(0.001 \mathrm{mmol} \mathrm{CO}_{2}\left(\mathrm{mmol} \mathrm{H}_{2} \mathrm{O}\right)^{-1}\right) ; d$ : intrinsic water use efficiency $\left(0.001 \mathrm{mmol} \mathrm{CO}_{2}\right.$ $\left.\left(\mathrm{mmol} \mathrm{H}_{2} \mathrm{O}\right)^{-1}\right) ; e$ : carboxylation efficiency of rubisco $\left(\mathrm{mol} \mathrm{m}^{-2} \mathrm{~s}^{-1} \mathrm{~Pa}^{-1}\right) ; f$ : maximum quantum yield of photosystem II (ØPSII $\left.=(\mathrm{Fm}-\mathrm{FO}) / \mathrm{Fm}\right) ; g$ : Falker chlorophyll index; *Different uppercase letters in the same column indicate differences according to the Scott-Knott's test at 5\% significance level. F - F value of each treatment. $\mathrm{F}_{\text {levene }}$ - Levene test. SW - Shapiro-Wilk test. ${ }^{\text {ns }}$ nonsignificant, * significant at $5 \%$. 
During plant adaptation to the environment, physiological processes act directly on leaf energy balance, mainly through gas exchanges, thus photosynthesis clearly stands out in plant biosynthesis (TAIZ; ZEIGER, 2013).

Figure 1 shows a low water availability to plants that is related to a lack of rainfall throughout the second experiment (beginning at 12 ten-day period), leading to water stress by dehydrating plant tissues and hence inhibiting leaf expansion. This inhibition is caused by a decreased turgidity of the cells, what directly affected transpiration in addition to a probable reduction in stomatal conductance (LARCHER, 2000).

If carbon assimilation is reduced, ATP and NADPH may accumulate, generating a surplus of energy in photo-protective pigments (chlorophylls and carotenoids) of the photosystems. This excess is unable to dissipate as heat, transferring it to oxygen, which becomes a reactive oxygen species (ROS) (TAIZ; ZEIGER, 2013). This fact could justify the lack of effect of the different pesticide mixtures on both chlorophylls (a and b), as well as the outcomes on PS II activity in both experiments.

Drought stress also leads to stomatal closure, restraining water vapor conductance and $\mathrm{CO}_{2}$ in leaves, and consequently limiting net photosynthesis rate, which could compromise plant yields (LOPES et al., 2011).

\section{CONCLUSIONS}

Physical-chemical properties of spray mixtures vary with the added products. Foliar fertilizer addition causes the largest changes, increasing spray solution $\mathrm{pH}$ and electrical conductivity.

The mixture of azoxystrobin, cyproconazole, zinc oxide, and manganese sulfate had no effect on triflumuron effectiveness to control Spodoptera Frugiperda in maize.

Plant physiological parameters (gas exchange and chlorophyll) were affected at different manners by each tank mixture. In experiment 1 , both water use efficiency and $\mathrm{CO}_{2}$ assimilation enhanced by the application of products. In experiment 2, the mixture of azoxystrobin, cyproconazole, zinc oxide, manganese sulfate, triflumuron, and adjuvant reduced carboxylation efficiency and intrinsic water use efficiency.

\section{ACKNOWLEDGEMENTS}

The authors thank the FAPEMIG, CNPq and CAPES, for financial support.

RESUMO: Têm-se atualmente poucos estudos sobre os efeitos de diferentes misturas de produtos fitossanitários na cultura do milho. A mistura em tanque é prática frequente a campo, mas sem o devido respaldo técnico. Os objetivos deste trabalho foram avaliar a eficácia de diferentes misturas em tanque no controle de Spodoptera frugiperda em um híbrido de milho convencional e os possíveis efeitos fisiológicos na planta, assim como as características físico-químicas da calda. O delineamento experimental utilizado foi o de blocos ao acaso (DBC), com quatro tratamentos e cinco repetições. O experimento foi repetido em duas épocas. Os tratamentos foram constituídos de diferentes misturas de produtos fitossanitários: 1- Inseticida (in) + Adjuvante (adj); 2 - in + adj + Fungicida (fg); 3 - in + adj + fg + fertilizantes foliares; 4 - testemunha. Foram avaliadas características físico-químicas da calda e número e tamanho de lagartas. Também foram realizadas avaliações de trocas gasosas com analisador de gás IRGA e de quantidade de clorofilas $a$ e $b$ com um clorofilômetro. As características físico-químicas de calda foram alteradas pelo uso de misturas de diferentes produtos fitossanitários. A adição de fertilizantes causou as maiores mudanças, aumentando o pH e a condutividade elétrica da calda. Não houve efeito da mistura de azoxistrobina, ciproconazol, oxido de zinco e sulfato de manganês ao triflumuron na eficácia de controle de Spodoptera Frugiperda na cultura do milho. As avaliações fisiológicas (trocas gasosas e clorofila) foram afetadas de forma distinta pelas misturas de produtos fitossanitários.

PALAVRAS CHAVE: Tecnologia de aplicação. Trocas gasosas. Propriedades físico-químicas. Zea mays.

\section{REFERENCES}

ANDRADE, D. J. de; FERREIRA, M. C.; FENÓLIO, L. G. Compatibilidade entre acaricidas e fertilizantes foliares em função de diferentes águas no controle do ácaro da leprose dos citros Brevipalpus phoenicis. $\mathbf{R}$. Bras. Frut., Jaboticabal, v. 35, n. 1, p. 39-50, 2013.

BAIO, F. H. R.; GABRIEL, R. R. F.; CAMOLESE, H. S. alteração das propriedades físico-químicas na aplicação contendo adjuvantes. Braz. J. Bios. Eng., Tupã, v. 9, n. 2, p. 151-161, 2015. 
BJÖRKMAN, O. Fluorescence in leaves and its relationship to photon yield of photosynthesis in photoinhibition. In: KYLE, D. J.; OSMOND, C. B.; ARNTZEN, C. J. Photoinhibition. Amsterdam: Elsevier, 1987. $123 \mathrm{p}$.

BURKHARDT, J.; HUNSCHE, M.; PARIYAR, S. Progressive wetting of initially hydrophobic plant surfaces by salts-a prerequisite for hydraulic activation of stomata? In: THE PROCEEDINGS OF THE INTERNATIONAL PLANT NUTRITION COLLOQUIUM, 16., 2009, Davis. Proceedings... Davis: Department of Plant Sciences, 2009. 10 p.

CASTRO, V. L. S. S. Uso de misturas de agrotóxicos na agricultura e suas implicações toxicológicas na saúde. J. Braz. Soc. Ecotox., Itajaí, v. 4, n. 1-3, p. 87-94, 2009.

CONAB - Companhia Nacional de Abastecimento. Acompanhamento da safra brasileira: grãos, oitavo levantamento, Maio/2016. Brasília: Conab, 2016. 178 p.

CUNHA J. P. A. R.; ALVES G. S. Características físico-químicas de soluções aquosas com adjuvantes de uso agrícola. Interc., Caracas, v. 34 n. 9, p. 655-659, 2009.

CUNHA, J. P. A. R.; ALVES, G. S.; REIS, E. F. Efeito da temperatura nas características físico-químicas de soluções aquosas com adjuvantes de uso agrícola. Pl. Daninha, Viçosa, v. 28, n. 3, p. 665-672, 2010.

DAVIS, F. M.; NG, S. S.; WILLIAMS, W. P. Visual rating scales for screening whorl-stage corn for resistence to fall armyworm. Mississippi: Agricultural and Forest Experiment Station, 1992. 9 p. (Technical Bulletin, 186).

DOPIERALA, K.; PROCHASKA, K. The effect of molecular structure on the surface properties of selected quaternary ammonium salts. J. Colloid Interface Sci., London, v. 321, n. 1, p. 220-226, 2008.

FEHR, W. R.; CAVINES, C. E. Stages of soybean development. Ames: Iowa State University of Science and Technology, 1977. $11 \mathrm{p}$.

FEIJÃO, A. R.; DA SILVA, J. C. B.; MARQUES, E. C.; PRISCO, J. T.; GOMES-FILHO, E. Efeito da nutrição de nitrato na tolerância de plantas de sorgo sudão à salinidade. R. Ci. Agron., Fortaleza, v. 42, n. 3, p. 675-683, 2011.

FERNANDES, O. D.; PARRA, J. R. P.; NETO, A. F.; PÍCOLI, R.; BORGATTO, A. F.; CLARICE G. B.; DEMÉTRIO, C. G. B. Efeito do milho geneticamente modificado Mon810 sobre a lagarta-do-cartucho Spodoptera frugiperda (J. E. Smith, 1797) (Lepidoptera: Noctuidae). R. Bras. Milho e Sorgo, Sete Lagoas, v. 2, n. 2, p. 25-35, 2003. https://doi.org/10.18512/1980-6477/rbms.v2n2p25-35

GAZZIERO, D. L. P. Mistura de agrotóxicos em tanque nas propriedades agrícolas do Brasil. PI. Daninha, Viçosa, v. 33, n. 1, p. 83-92, 2015.

GUERREIRO, J. C.; CAMOLESE, P. H.; BUSOLI, A. C. Eficiência de inseticidas associados a enxofre no controle de Spodoptera frugiperda em milho convencional. Sci. Agrar. Paranaensis, Marechal Cândido Rondon, v. 12, n. 4, p. 275-285, 2013.

HUSSAIN, R. A.; AHMAD, R.; NAWAZ, F.; ASHRAF, M. Y.; WARAICH, E. A. Foliar NK application mitigates drought effects in sunflower (Helianthus annuus L.). Acta Physi. Plantarum, Berlin, v. 38, n. 4, p. 1$14,2016$.

IOST, C. A. R; RAETANO, C. G. Tensão superficial dinâmica e ângulo de contato de soluções aquosas com surfatantes em superfícies artificiais e naturais. Eng. Agríc., Jaboticabal, v. 30, n. 4, p. 670-680, 2010. 
KISSMANN, K. G. Adjuvantes para caldas de produtos fitossanitários. In: GUEDES, J. V. C.; DORNELLES, S. B. Tecnologia e segurança na aplicação de agrotóxicos. Santa Maria: Departamento de Defesa Fitossanitária, Sociedade de Agronomia de Santa Maria, 1998. p. 39- 51.

LARCHER, W. Ecofisiologia Vegetal. São Carlos: RiMa, 2000. 529 p.

LEMES, E. M.; CASTRO, R. L. A.; SANCHES, M. C. Trocas gasosas foliares, fluorescência e teores de clorofila em milho com aplicação de inseticidas. In: SIMPÓSIO INTERNACIONAL DE TECNOLOGIA DE APLICAÇÃO, 7., 2015, Uberlândia. Anais... Uberlândia: UFU, 2015. p. 1-4.

LOPES, M.S.; ARAU, J. L.; HEERDEN, P. D. R.; FOYER, C. H. Enhancing drought tolerance in C4 crops. J. Exp. Bot., Oxford, v. 62, n. 9, p. 3135-3153, 2011.

MACIEL, C. D. G.; GUERRA, N.; OLIVEIRA NETO, A. M.; POLETINE, J. P.; BASTOS, S. L. W.; DIAS, N. M. S. Tensão superficial estática de misturas em tanque de glyphosate + chlorimuron-ethyl isoladas ou associadas com adjuvantes. PI. Daninha, Viçosa, v. 28, n. 3, p. 673-685, 2010.

PEREIRA, W. E.; SIQUEIRA, D. L.; MARTINEZ, C.; PUIATTI, M. Gas exchange and chlorophyll fluorescence in four citrus rootstoks under aluminium stress. J. Pl. Phys., Oxford, v. 157, n. 5, p. 513-520, 2000.

PUTTI, F. F.; GABRIEL FILHO, L. R. A.; BERTIN, F. H. A.; CREMASCO, C. P.; CATANEO, P. F; CHACUR, M. G. M.; HALMEMAN, M. C. R.; HALMEMAN, R. J. Characteristics and risks in the application of adjuvants in agricultural spraying. Braz. J. Biosyst. Eng., Maringá, v. 8, n. 2, p.173-182, 2014.

SILVA, F. M. L.; VELINI, E. D.; CORRÊA, T. M. Influência dos íons Ca, Mg, Cu e Zn na tensão superficial estática de soluções contendo surfatante. Pl. Daninha, Viçosa, v. 24, n. 3, p. 589-595, 2006

SILVA, F. L. B.; DE LACERDA, C. F.; NEVES, A. L. R.; DE SOUSA, G. G.; DE SOUSA, C. H. C.;

FERREIRA, F. J. Irrigação com águas salinas e uso de biofertilizante bovino nas trocas gasosas e produtividade de feijão-de-corda. Irriga, Botucatu, v. 18, n. 2, p. 304-317, 2013.

SOUSA, J. V.; RODRIGUES, C. R.; LUZ, J. M. Q.; SOUSA, V. B. F.; DE CARVALHO, P. C.; RODRIGUES, T. M.; DE BRITO, C. H Silicato de potássio via foliar no milho: fotossíntese, crescimento e produtividade. Biosc. J., Uberlândia, v. 26, n. 4, p. 502-513, 2010.

SUASSUNA, J. F.; DE MELO, A. S.; DA SILVA SOUSA, M. S.; DA SILVA COSTA, F.; FERNANDES, P. D.; PEREIRA, V. M.; BRITO, M. E. B. Desenvolvimento e eficiência fotoquímica em mudas de híbrido de maracujazeiro sob lâminas de água. Biosc. J., Uberlândia, v. 26, n. 4, p. 566-571, 2010.

TAIZ, L.; ZEIGER, E. Fisiologia Vegetal. 5. ed. Porto Alegre: Artmed, 2013. 918 p.

TORRES, L. G.; FERREIRA, E. A.; ROCHA, P. R. R.; FARIA, A. T.; GONÇALVES, V. A.; GALON, L.; SILVA, A. A. Alterações nas características fisiológicas de cultivares de cana-de-açúcar submetida à aplicação de herbicidas. Pl. Daninha, Viçosa, v. 30, n. 3, p. 581-587, 2012. 